\author{
Maria Amélia de Almeida Teles \\ Comissão da Verdade do Estado de São Paulo "Rubens Paiva" \\ União de Mulheres de São Paulo
}

\title{
Violações dos direitos humanos das mulheres na ditadura
}

Resumo: O artigo comenta sobre a situação geral das mulheres brasileiras nos anos de 1960 e 1970 enfatizando a participação de mulheres na luta contra a ditadura e o modus operandi do sistema repressivo misógino, que usou o corpo, a sexualidade e a maternidade como formas de intensificar a tortura ou exterminar cruelmente algumas militantes mulheres. Destaca o papel político da Comissão da Verdade por ter dado voz às mulheres vítimas, as quais só conseguiram falar em público, pela primeira vez, depois de mais de quatro décadas dos fatos ocorridos. Este texto também propõe que sejam devidamente investigados os crimes sexuais e crimes de gênero e apuradas as responsabilidades, ainda que tenham ocorrido há mais de 40 anos, pois são crimes de lesa-humanidade.

Palavras-chave: ditadura; crimes de gênero; tortura; mulheres; estupro.

\footnotetext{
(c) 0 Esta obra tem licença Creative Commons.

1 Paulo Evaristo ARNS; Henry SOBEL; e Jaime WRIGHT, 1986, p. 43.

${ }^{2}$ A Comissão Nacional da Verdade foi criada em 11 de novembro de 2012 pela lei 12.528 , aprovada no Congresso Nacional. Em seguida, foram criadas diversas comissões da verdade, e comenta-se que há ou houve mais de 100 destas comissões espalhadas pelo território nacional.

${ }^{3}$ Eu uso a expressão "ditadura militar" porque entendo que, apesar de ter havido a participação civil no golpe militar assim como durante a vigência da ditadura, o núcleo duro do Estado esteve sob a total responsabilidade dos militares das Forças Armadas, em especial do Exército.

${ }^{4}$ Setores das Forças Armadas, além
}

\section{Introdução}

As mulheres que nas prisões brasileiras tiveram sua sexualidade conspurcada e os frutos de seu ventre arrancados, certamente preferiram calar-se, para que a

vergonha suportada não caísse no domínio público.'

A Comissão da Verdade, ${ }^{2}$ apesar de ter sido instalada tardiamente, despertou no cenário público (mídia, escolas, universidades, sindicatos e parlamento) um interesse pelo que se passou no tempo da ditadura militar brasileira (19641985). ${ }^{3}$ A dificuldade encontrada por essa comissão de obter informações com as Forças Armadas ${ }^{4}$ e o Ministério das Relações Exteriores impediu o aprofundamento das investigações, em especial, sobre os mortos e desaparecidos políticos, mas também sobre as torturas praticadas contra mulheres, lésbicas, gays, transgêneros, nas populações negra, indígena e camponesa, e em diversas categorias de trabalhadoras e trabalhadores. Quando convocados, os agentes públicos responsáveis pelas violações aos direitos humanos quase 
de não terem colaborado com a Comissão da Verdade, proibiram os subordinados de prestarem informações à Comissão Naciona da Verdade. A ordem veiculada pelo ofício de 25/2/2014, enviada aos subordinados do Comandante do Exército, General Enzo Peri, proíbe qualquer colaboração para apurar os crimes da ditadura militar. Ele proíbe o atendimento a toda solicitação de informações referentes ao período de 1964 a 1985, feita seja pelo Poder Executivo (federal, estadual, municipal), seja pelo Ministério Público, pela Defensoria Pública ou por qualque pessoa. (Luiz Cláudio CUNHA 2014, não paginado).

${ }^{5}$ Infância Roubada, publicação da Comissão da Verdade do Estado de São Paulo "Rubens Paiva", datada de novembro de 2014, é parte relatório final dessa comissão e traz o depoimento de 42 crianças da época e de duas mães que tiveram seus filhos mortos. sempre se recusaram a responder às questões apresentadas pela comissão. Mesmo assim, ainda que de forma tímida, houve, pela primeira vez, de forma pública e ampla, a fala de vítimas, mulheres, indígenas, integrantes da população negra e crianças que à época tiveram sua infância roubada. ${ }^{5}$ Portanto, parte significativa da verdade, de fato, foi trazida à tona devido à vontade e/ou necessidade de sobreviventes e vítimas de tornarem públicas suas histórias silenciadas ao longo de décadas. Ao revelar os crimes como sequestros, torturas, assassinatos e ocultamentos de cadáveres, os crimes cometidos pelo emprego da violência de gênero, como os estupros, a violência sexual, os abortamentos forçados, entre outros, coloca-se a necessidade do avanço em direção à compreensão de que devem ser incluídos, de maneira autônoma, os crimes de gênero no rol daqueles considerados como as graves violações de direitos humanos, ou seja, os crimes de lesa-humanidade, e, portanto, imprescritíveis.

Neste texto, pretendo discutir, ainda que de forma bastante resumida, as condições enfrentadas pelas mulheres, no período da ditadura militar, tratando não só a participação de mulheres militantes políticas mas também o modus operandi do sistema repressivo que atuou de forma misógina, utilizou-se da discriminação de gênero para reforçar os estereótipos femininos de submissão e dependência emocional, afetiva e política. O tempo todo, a repressão política procurou coisificar e explorar a "condição de mulheres" para desmoralizar a militância de esquerda e reforçar as ideias mais retrógradas. No enfrentamento, no entanto, os repressores não deixaram de "reconhecer" a tenacidade e a capacidade de luta das mulheres para se empenhar na militância de esquerda e as torturaram igualmente como os demais e, sem ignorar suas diferenças, usaram delas para praticar as mais diversas e cruéis atrocidades.

O Relatório da Comissão Nacional da Verdade entregue à Presidenta da República, Dilma Roussef, no último dia 10 de dezembro, dedicou o capítulo 10 do volume I às denúncias da prática da violência sexual contra as mulheres, sequestradas e torturadas, nos órgãos de repressão política, conhecidos na época como de "segurança nacional". Nesse relatório, também foi publicada uma lista de 377 torturadores, na qual não consta o nome de nenhuma mulher; todavia, isso não significa que não houve a participação de mulheres na tortura.

Mostrar a situação das militantes políticas sequestradas, torturadas e muitas vezes assassinadas e introduzir informações que contextualizem a situação da população feminina naqueles anos de ditadura são as propostas deste texto. 
${ }^{6}$ Trata-se do assassinato de Carlos Nicolau Danielli (1929-1972), dirigente do PCdoB, ocorrido no dia 30/12/1972, no DOI-Codi/SP. ${ }^{7}$ Trata-se de Edgar Aquino Duarte (1941-1973).

\footnotetext{
${ }^{8}$ Safiotti descreve assim: "Logo no início do governo Juscelino Kubitschek, as autoridades brasileiras suspenderam o funcionamento de grande número de associações femininas, dentre as quais figuravam a Associação Feminina do Distrito Federal e a Federação de Mulheres do Brasil, à qual se filiava a primeira". (Heleieth SAFIOTII, 2013, p. 387).
}

Tive participação na militância política de esquerda contra a ditadura, fui sequestrada, torturada, pude ver outras militantes sendo torturadas, sou testemunha ocular de um assassinato sob torturas no DOI-Codi, ${ }^{6}$ em São Paulo, e cheguei a conhecer um militante que se tornou um "desaparecido político"7 no DEOPS/SP. Tive toda a minha família sequestrada pela repressão política, inclusive meus filhos de 4 e 5 anos de idade. Minha irmã (Crimeia de Almeida), grávida de oito meses, foi sequestrada e torturada. Meu sobrinho nasceu no cárcere. Além disso, tive várias amigas e amigos cujos nomes se encontram na lista dos mortos e desaparecidos políticos da ditadura. E é a partir dessa vivência trágica que trato das mulheres na ditadura.

\section{No pré-golpe}

Como enfrentar a discriminação histórica contra as mulheres?

Na fase pré-golpista, aqui considerada entre meados de 1950 até 1964, de um modo geral, as mulheres encontravam-se dispersas, e uma imensa maioria encontrava-se sob a influência de uma ideologia conservadora. As mulheres organizadas foram excluídas da políica antes do golpe. No governo de Juscelino Kubitschek, foi fechada a Federação de Mulheres do Brasil, o que é pouco falado até os dias de hoje. ${ }^{8}$ Essa organização de mulheres de caráter nacional, praticamente a única naqueles anos, foi criada por iniciativa do Partido Comunista com o objetivo de mobilizar "as massas femininas para as mudanças sociais". Na época do fechamento da Federação, os homens comunistas e demais progressistas não protestaram ou se manifestaram contrários; mantiveram, de uma certa forma, seu apoio acrítico ao governo do JK.

Naquela época, a maioria da esquerda não compreendia a "questão das mulheres" e não dava importância às suas lutas específicas. Havia mulheres militantes políticas de esquerda, mas não se proclamavam feministas, expressão que significava "mulheres burguesas ou quase", mulheres consideradas despolitizadas ou alienadas. Portanto, a ausência de organizações de mulheres de esquerda não foi sequer considerada como algo grave e não chegou a ser objeto de preocupação por parte de lideranças políticas num momento de ascensão dos movimentos populares.

Se a esquerda não percebeu a dispersão das mulheres, as forças de direita estavam atentas e passaram a incentivar a criação de organizações femininas com a finalidade de usá-las como base social de legitimação do golpe ao governo João Goulart, cuja preparação se encontrava em acelerado processo. Entidades financiadas pelos Estados Unidos, como o Instituto de Pesquisas e Estudos Sociais (IPES) e o Instituto 
9 “[...] vários grupos sociais, incluindo o clero, o empresariado e setores políticos diversos se organizaram em marchas, levando às ruas mais de um milhão de pessoas com o intuito de derrubar o governo Goulart. A primeira das 49 marchas foi em 19 de março (de 1964) - dia de São José, padroeiro das famílias - em São Paulo e congregou entre 300 e 500 mil pessoas. Ela foi organizada por grupos como Campanha da Mulher pela Democracia (CAMDE), União Cívica Feminina (UCF), Fraterna Amizade Urbana e Rural, Sociedade Rural Brasileira, dentre outros grupos, receberam o apoio da Federação das Indústrias do Estado de São Paulo (FIESP) e do controverso Instituto de Pesquisas Sociais (IPES) Na ocasião, foi distribuído o "Manifesto ao Povo do Brasil", pedindo o afastamento de Goulart da presidência. Após a deposição do presidente pelos militares em $1^{\circ}$ de abril de 1964, as marchas passaram a se chamar "Marcha da Vitória". A maior delas, articulada pela CAMDE no Rio de Janeiro, levou cerca de um milhão de pessoas às ruas no dia 2/04/1964." (MARCHA..., 2014).

10 René DREIFUSS, 1981, p. 291 apud Adriano Nuevo CODATO Marcus Roberto de OLIVEIRA, 2004, p. 208
Brasileiro de Ação Democrática (IBAD), sistematizavam estudos sobre os diversos segmentos da população com o objetivo de formular e implementar estratégias de controle da opinião pública brasileira, impondo o medo, ao anunciar o perigo que representava o comunismo internacional "infiltrado" no governo João Goulart. Tais entidades produziam informações falsas amplamente difundidas pelos meios de comunicação, buscando criar o clima favorável ao golpe militar, e reuniam mulheres de classe média alta, na sua maioria católicas, em organizações "femininas" tais como a Campanha das Mulheres pela Democracia (CAMDE), no Rio de Janeiro, e a Liga Democrática de Mulheres pela Democracia (LIMDE), em Belo Horizonte (MG). Essas organizações serviram de base fundamental para mobilizar amplas "massas femininas" para a concretização dos movimentos de triste memória: "Marcha com Deus Pela Família e Pela Liberdade" , quando colocaram milhares e milhares de mulheres em diversas cidades brasileiras, com o apoio explícito aos golpistas. Ao todo, em 1964, foram registradas 49 manifestações massivas de mulheres, por meio dessa marcha. ${ }^{9}$

As marchas organizadas por essas entidades femininas tinham o caráter ideológico antiesquerda $e$ anticomunista. Ao colocarem milhares de mulheres nas ruas, deixavam claras suas intenções anticomunistas, por meio de cartazes com dizeres: "Não à foice e martelo, pelo verde e amarelo!", "Vermelho só é bom no batom!"; e pediam a derrubada do Governo Goulart.

René Dreifuss apontou estratégias usadas pelos golpistas para desestabilizar o então governo democrático de João Goulart:

A mais significativa conquista do IPES no campo da mobilização política e ideológica consistia na utilização das classes médias como nova clientela política e o desenvolvimento de meios para mobilizálas, com êxito, como uma massa de manobra, efeito que os partidos e frentes tradicionais não se dispuseram ou se capacitaram a alcançar. A mobilização das classes médias conferia a aparência de amplo apoio popular à elite orgânica e a mídia coordenada pelo IPES proporcionava grande cobertura às atividades dessas classes médias mobilizadas. Na atmosfera como o ponto de referência para a identificação da legítima pressão popular. [Além de tudo,] o que o IPES viu como uma de suas conquistas de maior êxito foi a 'descoberta' dos grupos femininos de pressão, tão ampla e eficazmente usados dez anos mais tarde contra o governo constitucional de Salvador Allende, no Chile, e para os quais a experiência brasileira forneceu 0 modelo. ${ }^{10}$ 
Junto com essas manifestações veio o golpe militar de 1964, que implantou uma das ditaduras mais longas de nossa região. Instalou-se o estado ditatorial com base na Doutrina de Segurança Nacional, que definiu o inimigo interno como o principal a ser combatido. O inimigo tinha, portanto, de ser procurado entre o próprio povo. Prevaleceu a estratégia de que, em defesa da segurança nacional, eliminam-se as garantias constitucionais, a liberdade, os direitos da pessoa humana. Com a instalação da ditadura brasileira assegurada, inicia-se um novo ciclo de ditaduras nos países da região.

\section{Na ditadura militar}

Uma ferida que sangra sempre...

As mulheres, provavelmente, foram o segmento que mais se modificou nas décadas de 1960 e 1970 . Vivenciaram alterações na vida cotidiana, no mercado de trabalho, com a redução do número de filhos e, de forma veloz, precisaram obter mais escolaridade, o que transformou suas relações com os homens e com outras mulheres e mudou muito a dinâmica de suas vidas. Tudo isso ocorreu devido a vários fatores. O aceleramento da expansão do capitalismo, o crescimento do parque industrial, a negação e a proibição da reforma agrária e a expulsão da população do campo foram motivos suficientes para o deslocamento rápido da população rural para as áreas urbanas. As mulheres foram as primeiras a sentir essas mudanças. Sem as suas famílias por perto, com novas relações sociais, as mulheres obtiveram uma relativa independência, ainda que, muitas vezes, de forma compulsória e não consciente. As cidades cresceram sem a infraesturutra adequada, sem condições de moradia, cresceram as favelas, aumentaram os cortiços e houve um inchamento das periferias e dos subúrbios das capitais. $O$ crescimento do mercado de trabalho e o achatamento salarial levaram as mulheres a buscarem o trabalho remunerado.

Isso, por sua vez, propiciou um aumento significativo da participação feminina no mercado de trabalho. Em 1950, a mão de obra feminina representava $13,5 \%$ da força de trabalho; em 1976, as mulheres mais do que dobraram sua participação: passaram a ser $28,8 \%$; e, em 1985, as mulheres chegaram a $37 \%$, o que significou um crescimento maior da participação feminina do que da masculina.

Outro fator preponderante foi a descoberta da pílula anticoncepcional, em 1960, que possibilitou às mulheres experimentarem o prazer sexual sem medo de uma gravidez indesejada. Com uma nova dinâmica de vida, sem a infraestrutura necessária, sem creches e outros equipamentos sociais 


\footnotetext{
"Anticoncepcional injetável, com duração prolongada de até 3 meses. (Suzanne SERRUYA, [1987?]).
}

como restaurantes e lavanderias populares, as mulheres passaram a ter menos filhos e a se dedicar mais à profissionalização.

O feminismo no mundo se agitava numa onda libertária que reivindicava igualdade, direito ao próprio corpo, a politização do espaço privado, pois passou-se a compreender que o pessoal também é político, o direito ao prazer sexual, o direito de escolha.

No Brasil, a ditadura não dava tréguas. Colocou em prática o controle da natalidade por meio da Sociedade do Bem-Estar da Família (Bemfam), que realizou e acabou por impor esterilizações em massa e experimentações com substâncias reprovadas nos países europeus, como o DepoProvera. ${ }^{11}$ Essa droga foi largamente usada no Brasil, sem nenhum controle por parte das autoridades.

O governo militar assumiu uma postura ambígua: do ponto de vista oficial, mantinha-se numa política do não intervencionismo na vida reprodutiva. Na prática, abria caminhos, com subsídios e facilidades substanciais para ações antinatalistas, com acordos entre as secretarias de saúde e a Bemfam nos diversos estados brasileiros, priorizando a aplicação massiva de meios contraceptivos, ainda em fase experimental, junto à população pobre e em sua maioria negra. Os serviços públicos de saúde não ofereciam sequer informação e/ou orientação sobre o uso de contraceptivos. Sem acesso à assistência à saúde reprodutiva, a população feminina ficou à mercê das esterilizações e do uso inadequado de anticoncepcionais. O país passou a ter altos índices de esterilização feminina. Em Pernambuco, 18,9\% das mulheres de 15 a 44 anos estavam esterilizadas, por meio de ligadura de trompas. Em Manaus, $33 \%$ das mulheres encontravam-se com as trompas ligadas, no Piauí, $17 \%$ e, em São Paulo, 15\%. Estavam excluídas destes cálculos aquelas mulheres esterilizadas em decorrência de abortos inseguros ou pelo uso inadequado de anticoncepcionais ou do dispositivo intrauterino (DIU). Chegamos a uma situação absurda de reduzir drasticamente a natalidade em áreas de baixíssima densidade demográfica, como a Amazônia.

A censura foi adotada desde os primeiros dias da ditadura e se manteve durante todo o período ditatorial. Aliás, a misoginia da ditadura andava de mãos dadas com a censura. Houve, de maneira especial, a censura aos assuntos referentes às mulheres, sob alegação da defesa da família, da moral e dos bons costumes. A Revista Realidade, n. 10, de janeiro de 1967, foi totalmente vetada pela censura por abordar o resultado de uma pesquisa sobre o que as brasileiras pensavam. Foram entrevistadas 1.200 mulheres sobre casamento, parto e maternidade, sexualidade, 
12 Depoimento prestado por Carlos Azevedo a Comissão da Verdade do Estado de São Paulo "Rubens Paiva", 03/10/2013, na Assembleia Legislativa do Estado de São Paulo, dentro de uma série de audiências sobre a imprensa clandestina e alternativa.

${ }^{13}$ Cf. Documentário Cassandra Rios: A Safo de Perdizes! , de Hanna Korich (2013).

${ }^{14}$ Cf. José Miguel Nieto Olivar, antropólogo colombiano que fez a tese de doutorado: Devir puta, na Unicamp, e um dos únicos que estuda a relação da ditadura com as prostitutas. religiosidade. O motivo da proibição total foi, segundo Carlos Azevedo, ${ }^{12}$ jornalista da revista, a reportagem: "Assista um parto até o fim" com uma foto de uma mãe que acabava de ter o bebê. Era uma foto em que a mãe estava de costas e, portanto, não havia nenhuma exposição dos órgãos genitais da parturiente, apenas a cabecinha do bebê apontando. $O$ mesmo aconteceu com o Jornal Movimento n. 45 quase dez anos depois, em 1976. O jornal tratava da situação das mulheres no trabalho, até as tabelas do Instituto Brasileiro de Geografia e Estatísticas (IBGE) foram totalmente censuradas, a edição não chegou sequer às bancas. E também com Cassandra Rios (1932-2002), escritora de contos eróticos lésbicos, que foi a primeira mulher best-seller (chegou a vender um milhão de exemplares), teve a sua editora proibida de funcionar em 1976, pelo Ministro da Justiça, Armando Falcão. Foi a escritora mais censurada na ditadura. ${ }^{13}$

As prostitutas também foram alvo das mais diversas arbitrariedades por parte de policiais, militares e agentes públicos vinculados ao aparato repressivo, foram vítimas, inclusive, de sequestros e prisões, torturas e até assassinatos com a complacência do Estado. ${ }^{14}$

Lourdes Barreto, 71 anos de idade e 53 anos de exercício da prostituição, é uma das lideranças do movimento de profissionais de sexo e preside o Grupo de Mulheres Prostitutas do Pará, denunciou, em matéria assinada pelo jornalista Evandro Éboli, no jornal O Globo, em 21 de setembro de 2013, que a "zona do meretrício (com cerca de duas mil prostitutas) foi fechada pelos militares em 1971. O local foi invadido e lacrado por agentes da Marinha, da Aeronáutica e da Polícia Federal". Na mesma matéria, a travesti Safira Bengell, cujo nome de nascimento é João Alberto Souza, denunciou o quanto foi perseguida, presa e torturada: "Tínhamos que fazer sexo com os carcereiros e policiais para recebermos um pouco de água". Assim, a maioria das brasileiras, com informações truncadas ou sem informações, enfrentaram muitas dificuldades, mas não deixaram de lutar pela vida. Reinventaram novas formas de sobrevivência e de realização pessoal e social, mesmo sob a truculência da ditadura.

\section{As militantes políticas...}

[...] me espanta a capacidade que se tem de sobreviver ao horror... ${ }^{15}$

${ }^{16}$ Segundo o Projeto Brasil Nunca Mais, havia mais de 40 organizações de esquerda clandestinas. Ver livro Brasil Nunca Mais, 1985, $\mathrm{p}$. 114-116.

$$
\text { p. } 180 .
$$

${ }^{15}$ Susel de Oliveira da ROSA, 2013 
material impresso e o cuidado de casas (chamados de aparelhos) que serviam de base para estruturar as organizações e as atividades.

Essas organizações políticas foram duramente atingidas pela repressão, tiveram suas direções eliminadas pela ditadura, até aquelas que não participaram da luta armada sofreram o extermínio de suas direções. Houve mulheres sequestradas, torturadas, estupradas, assassinadas e desaparecidas. O Projeto Brasil Nunca Mais analisou os casos de 7.367 militantes processados pela justiça militar, e destes $12 \%$ eram mulheres. O Estado Maior do Exército fez um levantamento de presos políticos que se encontravam nos quartéis, num determinado momento do ano de 1970 e chegou a um total de mais de 500 militantes. Desse total, $56 \%$ eram estudantes, com idade média de 23 anos, $26 \%$ eram mulheres. Na Guerrilha do Araguaia, ocorrida no sul do Pará, entre 1972 e 1975, dos 70 guerrilheiros desaparecidos, $17 \%$ eram mulheres.

As torturas praticadas nas mulheres, assim como nos homens, faziam parte da estratégia política de Estado. Ainda sob a ditadura militar, homens e mulheres denunciaram perante a Justiça Militar as torturas sofridas, mesmo que isso representasse um sério risco que elas voltassem a acontecer. Segundo o Projeto Brasil Nunca Mais, 1843 pessoas denunciaram frente aos tribunais as torturas a que foram submetidas e nenhuma providência foi tomada, por parte da justiça militar ou de qualquer instância de poder, no sentido de investigar e impedir tais atrocidades.

A participação de mulheres nas organizações políticas clandestinas, de um modo geral, foi para garantir a infraestrutura das ações políticas e militares; na imprensa clandestina, pegaram em armas, viveram a clandestinidade de diversas formas, com outros nomes, outras identidades, deslocavam-se para várias partes do país ou para outros países, engravidaram, fizeram abortos ou tiveram filhos e os amamentaram, e choraram as perdas de pessoas queridas e amadas.

Em 1968, o mundo se agitava e se enchia de um clima revolucionário. Os negros nos Estados Unidos defendiam os direitos civis e protestavam contra a guerra imperialista no Vietnã. As manifestações estudantis e feministas estavam no auge nos Estados Unidos e na Europa e levantaram a necessidade das revoluções cultural e sexual. Nesse mesmo ano, no Brasil, os estudantes protestaram em passeatas contra a ditadura e, ao mesmo tempo, eclodiram as greves operárias contra o arrocho salarial e a intervenção da ditadura nos sindicatos. As mulheres brasileiras intensificaram sua participação política, seja nas passeatas, seja nas fábricas, seja na clandestinidade. 


\section{Greve, abortamento forçado e estupro}

${ }_{17}$ Maria Amélia de Almeida TELES, 1993, p. 111.

${ }^{18}$ Amelinha TELES; Rosalina Santa Cruz LEITE, 2013, p. 26.

${ }^{19} \mathrm{O}$ trecho transcrito foi publicado no Jornal Tribuna de Imprensa, Rio de Janeiro, 6/12/1969. (Bernardo KUCINSKI; Ítalo TRONCA, 2013, p. 158).

${ }^{20}$ KUCINSKI; TRONCA, 2013, p. 114.
Trabalhamos mais e somos mais desvalorizadas. ${ }^{17}$

A greve de Contagem (MG) foi a primeira e, de certa forma, foi uma surpresa para a ditadura militar. Foi deflagrada no dia 16 de abril de 1968 pelos metalúrgicos da Siderúrgica Belgo-Mineira. Esses trabalhadores foram acompanhados por outros de outras empresas como a Mannesmann, a Mafersa, a RCA Victor, a Acesita e tantas mais. A liderança que conduziu a greve com muito sucesso e que, até hoje, quase nunca é lembrada foi uma mulher, Conceição Imaculada de Oliveira. ${ }^{18}$ Algum tempo depois, ela foi presa, grávida:

A repressão não se esqueceu da Conceição, secretária do Sindicato de Metalúrgicos a que o ministro Passarinho (Coronel do Exército Jarbas Passarinho que àquela época era Ministro do Trabalho) queria encontrar na época da mobilização da massa operária. Presa grávida, foi submetida a um aborto criminoso em uma sala comum do DOPS de Belo Horizonte (MG), na presença dos demais presos políticos e dos policiais. [...] para assistir [...] à cirurgia, praticada sem anestesia, sem nenhum cuidado higiênico e inclusive sem os instrumentos cirúrgicos necessários para uma operação. Quando, impotente, a vítima gritava, os torturadores faziam um alarido histérico e sádico, gritavam de alegria, diziam palavrões aos indignados espectadores mantidos sob ameaças dos fuzis. ${ }^{19}$

Gilse Avelar, integrante do movimento popular de apoio às greves de Minas e levada à prisão junto com outras quatro mulheres: Loreta Kiefer Valadares, Delcy Gonçalves, Maria do Rosário Cunha Peixoto e Laudelina Maria Carneiro, relatou:

[...] em 23 de agosto de 1969, fui levada à presença do tenente-coronel Valdir Teixeira Góes, do $12^{\circ}$ Regimento $\left(12^{\circ}\right.$ RI localizado no bairro de Barro Preto, em Belo Horizonte-MG), que informou que eu seria entregue aos torturadores capitão Jesu e sargento Leo, ambos da Polícia Militar, que se encarregariam de espancar-me, colocar-me no pau-de-arara, divertir-se com meu corpo e, finalmente, violentar-me [...]. Às $19 \mathrm{hs}$ fui conduzida até um posto policial isolado. [...] depois de ser violentamente despida, até ficar totalmente nua, estive durante nove horas sob a sanha desses policiais, que se revezavam em combinações de torturas físicas, psicológicas e sexuais. ${ }^{20}$

Loreta Kiefer Valadares declarou:

[...] por ordem do tenente-coronel Góes, fui levada pelo capitão Jesu ao Colégio Militar (de Belo Horizonte 
(MG), onde fui submetida a torturas físicas, morais e sexuais perpetradas pessoalmente pelo capitão Gomes Carneiro, do Exército, na presença do tenente Marcelo. As torturas consistiam em carícias por todo o corpo, abraços e sussurros nos ouvidos, logo transformados em golpes de caratê no estômago, bofetadas e principalmente vários golpes de "telefone" nos ouvidos, que quase me deixaram surda [...]. ${ }^{21}$

\section{A menstruação}

\begin{abstract}
${ }^{22}$ Elisa Lucinda, atriz e poeta. Este verso faz parte da publicação de autoria de Elisa Lucinda: "A Lua que Menstrua", publicação independente, de 1992. (WIKIPEDIA, 2015. Disponível em: <https://pt. wikipedia.org/wiki/Elisa_Lucinda $>$. Acesso em: 18 de jun. 2015).
\end{abstract}

${ }^{23}$ Participei dessa mesa junto com Hillary Hiner e a professora da USP Flávia Schilling.
Moço, cuidado com ela
Há de se ter cautela com essa gente que menstrua...

No DOI-Codi/SP, em janeiro de 1973, havia uma conversa entre as mulheres ali encarceradas de que os torturadores não gostavam de estuprar mulheres menstruadas. Então, guardávamos um absorvente usado e que estava sujo de sangue e o colocávamos rapidamente dentro da calcinha quando éramos levadas para os interrogatórios, que na realidade eram sessões de tortura. É interessante lembrar que uma pesquisadora do Chile disse que as presas políticas chilenas também usaram desse mesmo expediente. ${ }^{23}$

Artur Scavone, ex-preso político, deu depoimento na Comissão da Verdade "Rubens Paiva" e falou de uma militante do Molipo (Movimento de Libertação Popular), Maria Augusta Thomaz, que foi assassinada pela ditadura, em 17/ 5/1973 e até hoje é "desaparecida política". Scavone disse que ela participou do treinamento em Cuba, e é importante dizer isso, contra a vontade dos companheiros.

Ela me contou isso e dizia que em Cuba também tinha machismo muito forte. [...] o objetivo da guerrilha no Brasil era chegar no campo. E quando se discutiu isso, havia uma visão de não ir mulheres, porque mulheres menstruam, tem problemas, tem uma certa dificuldade, etc. e etc. Mas Maria Augusta não aceitou isso e ela foi junto com os demais companheiros para o treinamento e ela falava com muito orgulho disso. Havia uma graduação entre todos os companheiros que faziam o treinamento. E Maria Augusta, apesar de ter feito o mesmo treinamento que os homens, ficou na $2^{a}$ posição.

\section{A misoginia da ditadura}

As mulheres, militantes políticas à época, subverteram a ordem patriarcal tão solidamente acomodada na ideologia ditatorial.

A participação das mulheres se deu por decisão delas próprias. Ao assumirem uma posição política de transformar a ditadura em liberdade, justiça e democracia, passaram a engrossar as diversas trincheiras de lutas, das ações políticas

1010 Estudos Feministas, Florianópolis, 23(3): 1001-1022, setembro-dezembro/2015 
${ }^{24}$ Andrea ANDÚJAR et al., 2009, p. 28 e seguintes.
${ }^{25}$ ANDÚJAR et al., p. 29. Esse depoimento foi publicado originalmente no livro: BEGUÁN, Viviana et al. Nosotras, presas políticas. 1974-1983. Buenos Aires: Editora Nuestra América, 2006.

${ }^{26}$ COMISSÃO DE FAMILIARES DE MORTOS E DESAPARECIDOS POLÍTICOS, 2009, p. 389. de repúdio à ditadura, seja de luta armada ou não, o que irritou profundamente os militares que esperavam que elas fossem facilmente dominadas e controladas por eles. Eles não aceitavam que as mulheres pudessem exercer livremente o seu direito de escolha, inclusive de lutar contra a ditadura. Eles odiavam as militantes que fugiam do estereótipo da submissão, da dependência e da incapacidade de tomar decisão. A tortura foi amplamente usada contra mulheres e homens. No entanto, as mulheres foram submetidas de forma mais intensa à tortura sexual, como os estupros, as mutilações, inclusive, com uso de animais vivos.

Os militares, de início, subestimaram a capacidade das mulheres, mas, ao vê-las atuando na luta, inclusive com uso de armas, tiveram reações de ódio e repúdio. Isso porque as militantes políticas daquela época romperam com preconceitos e barreiras machistas. Tiveram até que enfrentar a própria organização política de esquerda em que atuavam. A esquerda também tinha preconceito e as discriminava. Assim, as militantes tiveram que subverter a ordem do estado ditatorial e a ordem interna de suas organizações políticas. Eram duas vezes subversivas. ${ }^{24} \mathrm{~A}$ ditadura as via como uma ameaça, daí se justificava a censura aos temas sobre mulheres, o que aconteceu no Brasil, na Argentina e em outros países da região. se repete num relato de Liliana Chiernajowisky que se refere ao ano de 1977, quando estava presa no cárcere de Villa Devoto (Buenos Aires). [...] ela contou que $o$ chefe [...] disse (quando viu as presas políticas chegarem no presídio): preferia que me mandassem todos os líderes guerrilheiros do que ter que lidar com estas loucas. As mulheres são piores, quando acreditam em algo o levam nas entranhas. Os homens são mais razoáveis. ${ }^{25}$

Como assessora da Comissão da Verdade "Rubens Paiva", tive oportunidade de ter contatos com documentos da repressão política (DOI-Codi, Cenimar, Cisa, Dops, entre outros) e também de ouvir relatos de militantes. Não era raro ver que as militantes mulheres recebiam um tratamento bastante diferente dos militantes homens. Os documentos, quando se referiam à mulher, usavam expressões como "ativa fanática em subversão", "bom grau de inteligência" "moça de muita valentia". ${ }^{26}$ Eles nunca diziam que um homem era fanático, ou mesmo, inteligente. A premissa básica é de que os homens são inteligentes, valentes e racionais, portanto, não seria necessário mencionar isso no relatório a seu respeito. A repressão tratou as mulheres como muito perigosas, pois elas queriam "superar os homens", eram consideradas promíscuas porque eram capazes de abandonar seu "papel social" 
${ }^{27}$ ANDÚJAR et al., p. 27.

${ }^{28}$ Lucia Maria de Souza (1944-1974) pertencia ao Destacamento A da Guerrilha do Araguaia.

29 Ato Institucional n. 5, editado em 13/12/1968, que acirrou a repressão política.
${ }^{30}$ TELES. Breve História do Feminismo no Brasil, Editora Brasiliense, São Paulo, 1993, p. 71

${ }^{31}$ Munú ACTIS et al., 2006, p. 66. a ponto de aspirar ao poder políico e participar da luta armada. É interessante notar que homens da esquerda também consideravam as mulheres ativistas políticas como um pouco "esquemáticas", "dogmáticas", "totalmente entregues à causa", ${ }^{27}$ O Relatório da Operação Sucuri, que trata da primeira campanha militar contra a Guerrilha do Araguaia, ao descrever a guerrilheira Lucia Maria de Souza (Sônia), ${ }^{28}$ a descreve como uma mulher de corpo bonito. Nenhum guerrilheiro recebeu uma descrição desse tipo.

Vera Silvia de Araújo Magalhães (1948-2007) participou da guerrilha urbana no Rio de Janeiro. Com 21 anos de idade, era uma das jovens universitárias que passou ao movimento guerrilheiro depois da edição do Al-5. ${ }^{29}$ Pertenceu ao MR-8 (Movimento Revolucionário 8 de Outubro) e foi a primeira mulher de sua organização a se incorporar à luta armada. A imprensa tradicional se referia a ela como "a terrível mulher loura", ou "a loura 90", como se ela usasse duas metraIhadoras ao mesmo tempo. Em entrevista à TV Senado, ela conta que no início "não acreditava em sua capacidade para ser guerrilheira" e, no entanto, tornou-se referência para o movimento guerrilheiro. Mas ela fala que enfrentou discriminação por ser mulher. Segundo ela: "Eu era a única mulher no meio de sete homens. Fiz um puta esforço para chegar lá. A minha militância política foi uma batalha, porque, além de tudo, havia o preconceito machista".

Criméia Almeida (ex-guerrilheira da região do Araguaia) afirma:

[...] a expectativa do comando guerrilheiro era de que a mulher tivesse a mesma força física, os mesmos costumes e a mesma frieza para lidar com as emoções e duvidavam de nossa capacidade para desempenhar as tarefas militares.[...] Algumas guerrilheiras tentaram se aproximar do modelo masculino. Acreditavam que dessa forma seu desempenho seria melhor nas ações militares. Mas houve aquelas que aprenderam que deviam afirmar a diferença e buscar novas formas de vida e de fazer política. [...] Nas estratégias militares, coube às mulheres executar as tarefas de observação, levantamento de informações e preparação do apoio logístico. Mas o comando ficou a cargo dos homens. Só excepcionalmente ele coube a uma ou outra mulher. ${ }^{30}$

\section{O uso de animais vivos nas sessões de tortura e a morte da guerrilheira}

A tortura se foi, mas dura a vida toda. ${ }^{31}$

A repressão, ao combater as mulheres de esquerda, tratou-as com requintes de crueldade, e os torturadores faziam questão de afirmar que os interrogatórios eram feitos 
${ }^{32}$ Notas da autora que ouviu essas declarações dos torturadores Alemão, Lourival Gaeta e Aparecido Laertes Callandra (Capitão Ubirajara), no Doi-Codi de SP em 1972 e 1973.

${ }^{33}$ Lucia Murat foi presa política e torturada na ditadura militar brasileira. Nasceu em 1949, no Rio de Janeiro. É cineasta com diversos filmes premiados, entre eles "Uma longa viagem" e "Quase dois irmãos". Aqui cito trecho de seu depoimento à Comissão Nacional da Verdade, no Rio de Janeiro, em 28/5/2013.

${ }_{34}$ BRASIL, 2014 a, p. 374.

${ }^{35}$ BRASIL, 2014a, p. 373-374.

${ }^{36}$ Depoimento de Maria Amélia de Almeida Teles (a autora do texto) na Comissão da Verdade "Rubens Paiva", na audiência de "Verdade e Gênero", em 4/3/2013. sob "rigorosa metodologia científica". "Aqui só morre quem a gente quer", eles diziam. ${ }^{32}$ Eles usaram vários métodos de tortura. Usaram também animais e insetos vivos para praticarem torturas em homens e mulheres. Lucia Murat ${ }^{33}$ assim relatou em depoimento à Comissão Nacional da Verdade: ${ }^{34}$

\begin{abstract}
Eu não sei bem o que se passou quando eu voltei. As lembranças são confusas. Eu não sei muito bem como era possível, mas sei que tudo ficou pior. Eles estavam histéricos, eles sabiam que precisavam extrair alguma coisa em 48 horas, se não perderiam o meu contato. Gritavam, me xingavam, me puseram de novo no pau de arara [sic]. Mais espancamento, mais choque, mais água e dessa vez entraram as baratas. Puseram baratas passeando pelo meu corpo, colocaram uma barata na minha vagina. Hoje parece loucura, mas um dos torturadores de nome de guerra 'Gugu' tinha uma caixa onde ele guardava as baratas amarradas por barbantes e através do barbante ele conseguia manipular as baratas pelo meu corpo.
\end{abstract}

Há mais denúncias, no Relatório final da Comissão Nacional da Verdade, de uso de animais vivos:

Presos políticos foram expostos aos mais variados tipos de animais, como cachorros, ratos, jacarés, cobras, baratas, que eram lançados contra o torturado ou mesmo introduzidos em alguma parte de seu corpo. Especificamente em relação aos camundongos, o torturador Lourival Gaeta, que atuou no DOl-Codi do II Exército, em São Paulo, durante a década de 70 , explicava sua destrutividade uma vez introduzidos nos corpos das suas vítimas, com o argumento de que este animal não sabe andar pra trás. ${ }^{35}$

É de se imaginar que as vítimas submetidas a esse tipo de tortura feita por Lourival Gaeta deveriam morrer, em seguida, com hemorragia interna, pois os camundongos iam corroendo seus órgãos internos.

Há ainda denúncias sobre esse torturador, que praticou outras formas de tortura, como violência sexual:

[...] Eu estava sentada na cadeira de dragão, nua amarrada com fios de metal, levando choque no corpo todo, ânus, vagina. Enquanto isso, o Gaeta, que era um torturador, estava se masturbando e jogando esperma em cima do meu corpo nu...[...] Num outro momento, estava sendo torturada em pé, nua e cai no chão. Ele (o Gaeta) me pegou e me colocou numa cama de lona que estava na sala de torturas e começou a esfregar meus seios, apertar minha bunda [...]. ${ }^{36}$ 
37 COMISSÃO DE FAMILIARES DE MORTOS E DESAPARECIDOS POLÍTICOS 2009, p. 500-506.
${ }^{38}$ Lourival Gaeta (1927-1997) era delegado do DOPS de São Paulo e integrou-se à equipe de torturadores da Operação Bandeirante ou DOI-Codi/SP. Era chamado também de "Mangabeira". (N.A.)

${ }^{39}$ BRASIL, 2014b, p. 467.

${ }^{40}$ Leonencio NOSSA, 2012, p. 161. Cristina era o nome de guerra da guerrilheira Jana Moroni Barroso, e esse trecho seria uma conversa que ela teve com um dos moradores da região que the pedia para fugir, pois o Exército iria pegá-la e matá-la.

${ }^{41}$ Seus nomes são: 1. Áurea Eliza Pereira Valadão (1950-1974); 2. Dinaelza Soares Santana Coqueiro (1949-1974); 3. Dinalva Oliveira Teixeira (1945-1974); 4.Helenira Rezende de Souza Nazareth (19441972); 5. Jana Moroni Barroso (1948-1974); 6. Lúcia Maria de Souza (1944-1973); 7. Luiza Augusta Garlippe (1941-1974); 8. Maria Célia Correa (1945-1974); 9. Maria Lucia Petit da Silva (1950-1972) 10. Suely Yumikom Kayamana (1948-1974); 11. Telma Regina Cordeiro Correa (1947-1974); 12 Walkíria Afonso Costa (1947-1974).
Sonia Maria Lopes de Moraes Angel Jones, de 27 anos de idade, foi sequestrada, juntamente com Antônio Carlos Bicalho Lana, 25 anos, pelos agentes do DOI-Codi/SP, em novembro de 1973. Ambos foram assassinados. Sonia havia sido casada com Stuart Angel, também sequestrado, torturado, assassinado, cujo corpo nunca foi entregue aos seus familiares. Antes de ser assassinada, Sonia foi estuprada. O pai de Sonia Maria, tenente-coronel da reserva do Exército brasileiro e professor de matemática, João Luiz de Morais, denunciou seu assassinato sob torturas enquanto viveu.

Minha filha foi morta nas dependências do Exército Brasileiro, enquanto seu marido Stuart Angel foi morto nas dependências da Aeronáutica do Brasil. Tenho conhecimento de que, nas dependências do DOI-Codi do I Exército (SP), minha filha foi torturada durante 48 horas, culminando essas torturas com a introdução de um cassetete da Polícia do Exército em seus órgãos genitais, que provocou hemorragia. ${ }^{37}$

Todas as investigações não confirmam exatamente a data da morte da Sonia, mas o atestado de óbito, feito a pedido do DOI-Codi/SP, informa que ela teria morrido em consequência de hemorragia interna por ferimento de arma de fogo, sem nenhuma referência aos sinais evidentes de tortura. Informações dadas à Comissão Nacional da Verdade por testemunha ocular, cuja identidade é mantida em sigilo, indicam que Sonia estava deformada e ainda foi torturada com um rato introduzido em sua vagina. Os responsáveis pelas atrocidades vividas por Sonia, assim como sua morte, seriam o chefe de interrogatórios, Lourival Gaeta, ${ }^{38}$ que atuava no DOI-Codi/SP, e os integrantes de sua equipe. ${ }^{39}$

\section{Guerrilheiras do Araguaia}

Meu lugar é aqui junto com meus companheiros, lutando para livrar o país dessa ditadura fascista [...] No futuro não se esqueça de contar a nossa história. ${ }^{40}$

Dos 70 guerrilheiros desaparecidos no Araguaia, 12 são mulheres. ${ }^{41}$ Saíram de cidades grandes e se enveredaram na selva para conquistar justiça social, liberdades e o fim da ditadura militar. Fizeram um grande esforço pessoal, cada uma delas, para se tornarem guerrilheiras na selva amazônica uma das maiores florestas, com uma grande biodiversidade, que exige uma adaptação enorme para sobrevivência. As mulheres se esforçaram e conseguiriam sobreviver não fosse a truculência das Forças Armadas, em particular do Exército brasileiro. Elas aprenderam a usar armas, a se rastejar na selva, a se orientar por dias e dias, a atravessar rios a nado, a subir em árvores, a plantar roça, a fazer partos, curativos e extração de dentes, a dar aulas para uma população 
42 Jornal do Brasil, 1992.

${ }^{43}$ Jornal do Brasil, 1992. analfabeta e abandonada pelo Estado, a fazer caçadas, entre tantas coisas necessárias para sobrevivência na selva. As guerrilheiras trabalharam também na costura de roupas para os integrantes do movimento, prepararam e organizaram depósitos de alimentação e medicamentos, e houve até uma delas, Walquiria, que cantava, tocava instrumentos (violão e acordeom) e compunha músicas. Com tanta participaçãoe empenho, não chegaram a ocupar cargos importantes na guerrilha, com exceção de Dinalva Oliveira Teixeira, que chegou a ser vice-comandanta. Ela foi a primeira e única mulher a ocupar cargo de chefia na guerrilha rural. Dina, como era conhecida, às vezes foi confundida com outra baiana, que também estava na guerrilha, a Dinaelza, que era conhecida como Maria Dina. As duas eram consideradas pelos militares mulheres muito valentes.

Em vários confrontos, Dinalva, chamada de Dina na guerrilha, conseguiu escapar e dar continuidade à luta. Num desses confrontos, ela levou um tiro de raspão no pescoço, mas conseguiu escapar, fugindo para o mato, enquanto os demais guerrilheiros foram mortos.

Correm pela mata do Araguaia, os feitos de Dina, seus confrontos com equipes do Exército, e sua fama de boa atiradora e combatente destemida.

[...] Com sensação de derrota por não ter capturado os mitos Dina e Osvaldão e pressionado a encerrar um conflito que poderia ganhar impacto no exterior, o Exército mudou de tática no Araguaia. ${ }^{42}$

\section{Segundo Élio Gaspari, no livro A Ditadura Escancarada,}

[...] a mitológica Dina foi assassinada grávida. Ela estava sob o controle do major Curió. [...]. As informações sobre essa guerrilheira são de que ela teria sido sequestrada juntamente com outra guerrilheira, Luiza Garlippe, por uma equipe de militares sob o comando do major Curió, numa emboscada. O próprio major já confirmou isso em diversas entrevistas. ${ }^{43}$

Dina estava, portanto, totalmente sob o controle do Exército, era uma das últimas guerrilheiras que ainda sobrevivia às atrocidades perpetradas por essa instituição.

O nome de Dinalva era um dos poucos não riscados na folha pregada na parede da Casa Azul (um dos centros clandestinos de tortura e de extermínio, mantido pelo Exército brasileiro). Era a 'peça' que faltava para o Exército considerar extinta a guerrilha. Com a mulher que virava borboleta, pomba e cupim livre na mata, a vitória da repressão jamais seria assimilada pelos caboclos nos barrancos dos rios, garimpos e povoados, acreditavam os militares. O mito Dina se comparava ao de Perpetinha, a menina sequestrada por índios no 
44 Jornal do Brasil, 1992, NOSSA, Leonêncio. Mata! O major Curió e as guerrilhas do Araguaia. São Paulo: Compania das Letras, 2012 p. 209.

${ }^{45}$ COMISSÃO DE FAMILIARES DE MORTOS E DESAPARECIDOS POLÍTICOS, 2009, P. 583

${ }^{46}$ ODOI-Codi do II Exército foi criado inicialmente com o nome de Operação Bandeirante (OBAN). ciclo do caucho. Mais de cem anos depois do rapto, ela ainda deixava mensagem nos troncos das árvores: "Por aqui passou Perpetinha". ${ }^{44}$

Sabe-se pouco sobre o assassinato de Dina e o que aconteceu com a sua gravidez. Morreu grávida ou teria tido sua criança antes de morrer?

O major Curió relatou, em entrevista no dia 4 de março de 2004, no Estado de São Paulo, que:

[...] a operação para tirar de combate os principais comandantes da Guerrilha do Araguaia, Osvaldo Orlando da Costa, o Osvaldão, a Dinalva de Oliveira Teixeira, a Dina, foi definida numa reunião do presidente Garrastazu Médici com o Alto-Comando do Exército. ${ }^{45}$

O Exército brasileiro tinha medo da Dina viva, pois ficaria com sua moral abalada se não tirasse a vida da guerrilheira.

\section{O estupro de uma adolescente}

Prevaleciam o silêncio, o medo, a vergonha, a humilhação..

Filha do General Zerbini (cassado pelo golpe militar de 1964) e de Terezinha Zerbini, mulher que se destacou na luta pela anistia aos presos e perseguidos políticos, Eugênia Zerbini tinha 16 anos de idade, em 1970, quando sua mãe foi levada presa para a OBAN. ${ }^{46}$ Isso aconteceu no dia 11 de fevereiro de 1970, quando homens à paisana, portando metralhadoras, foram até sua casa buscar Terezinha porque ela estava sendo acusada de dar apoio à subversão. Um deles se apresentou como sendo "Capitão Guimarães". Dois dias depois, Eugênia foi à Oban levar roupas íntimas, escova de dente e outros objetos de higiene pessoal para sua mãe. Ao chegar lá, ela falou que:

[...] era filha do General Zerbini e queria falar com o oficial do dia [...]. Logo em seguida veio alguém. Assim, ninguém usava crachá, ninguém! Ele veio e fomos para uma sala. A única coisa que me chamou a atenção era uma sala muito nua, não tinha nada de referência, não tinha folhinha, não tinha uma imagem, não tinha nada para se ter referência. Nem a fotografia do Garrastazu Médici que, em todos os lugares públicos estava. Ele disse: "O que você veio fazer aqui?". Eu disse: "Eu vim trazer essas coisas para a minha mãe". E ele: "O que a sua mãe fez?" Aí, até hoje eu me arrependo, eu falei: "Vocês devem saber melhor do que eu, porque vocês a prenderam e não eu". Eu acho que eu não devia ter dito aquilo. Ele respondeu: "Ah! Pois não". Levantei e aí ele me agarrou e eu fui violentada ali. Eu não sei como eu saí, aquelas coisas assim, estava muito confuso, de repente eu estava na

1016 Estudos Feministas, Florianópolis, 23(3): 1001-1022, setembro-dezembro/2015 
${ }^{47}$ Eugenia Zerbini, 60 anos à época do depoimento prestado na audiência da Comissão da Verdade "Rubens Paiva", na Assembleia Legislativa do Estado de São Paulo, em 9/4/2013.

${ }^{48}$ Fala de Criméia de Almeida, exguerrilheira do Araguaia (TELES, 1993, p. 72).

${ }^{49}$ ANDÚJAR et al., 2009, p. 27 rua. [...]. Não tive coragem de contar para ninguém, nem para o meu pai, nem para minha vó [...]. A gente sente vergonha...[...] Agora que tornei público isso, fiquei mais leve. Sei que não foi a mim, eles estavam fazendo isso para atingir meu pai e minha mãe. E eu fui um veículo que estava à mão. ${ }^{47}$

Eugênia ficou em silêncio por 43 anos, de 1970 até 2013, quando ela deu o depoimento. Na ocasião, ela pediu à Comissão da Verdade para identificar o funcionário que ocupava o cargo de "oficial do dia" na OBAN (DOI-Codi/SP), no dia 13 de fevereiro de 1970, por volta das 15 horas. O Exército não deu nenhuma informação até o momento.

\section{Maternidade}

[...] à ameaça de morte, podemos responder com uma nova vida... $^{48}$

As militantes foram mulheres diferentes, despojadas. Muitas tiveram suas crianças na clandestinidade. Crianças que, em muitos casos, não puderam ter seus nomes verdadeiros e não sabiam os nomes de seus pais devido às perseguições sem trégua. Isso obrigava seus pais e suas mães a manterem identidade falsa inclusive para suas crianças. Muitas conceberam e pariram seus filhos em situações de extremo risco. Foram mães inéditas. ${ }^{49}$ Houve mães cujas crianças nasceram sob a ameaça de tortura nas prisões. Nos países vizinhos, houve sequestro dos bebês pelos militares. Aqui no Brasil, houve, no Araguaia, pelo menos uma criança nascida em cativeiro e sequestrada. A maternidade foi um dos meios de tortura utilizados pela repressão política. Foi usada para enlouquecer e fragilizar militantes, o que causou, em muitas situações, o enfraquecimento afetivo e emocional às mulheres e às crianças. As mães, por serem violentamente reprimidas pela ditadura devido à militância política, eram obrigadas a assistir suas crianças serem submetidas às mais vis torturas psicológicas ou físicas. Houve mães que sequer eram militantes, mas seus companheiros eram e, portanto, suas crianças foram submetidas a sequestros, ameaças de torturas ou chegaram a ver o assassinato de seus pais sob tortura.

As crianças foram atingidas porque suas mães, na maioria dos casos, romperam com os estereótipos femininos, saíram dos papéis impostos de submissas e frágeis e se empenharam em ações que eram consideradas "de homens", como o manejo de armas, a elaboração de estratégias políticas de enfrentamento e resistência na tentativa de obter justiça, liberdade e democracia. Eram mulheres que já tinham conquistado mais independência e autonomia. Para isso, tiveram que superar muitas barreiras nos campos pessoal, familiar, profissional, cultural e político. Tiveram que assumir o 
protagonismo de suas vidas, de suas escolhas. Tornaram-se sujeitos históricos e políticos. Trouxeram para o plano político de suas organizações as questões pessoais do cotidiano, inclusive a gravidez, a maternidade, o abortamento.

Aqui, refiro-me ao caso de uma criança que sabemos ter nascido em cativeiro, embora ainda não saibamos exatamente quem era sua mãe. Lia Cecília é o nome da criança, hoje uma mulher adulta com 40 anos de idade, nascida em 1974 na região da guerrilha do Araguaia, filha do guerrilheiro desaparecido Antônio Teodoro de Castro (1945-1974), cujo nome de guerra era Raul. Sob o título: "Sou a prova de que mesmo na guerra existiu um grande amor", na página 305 do livro citado acima, Lia deixa o testemunho de sua "infância roubada", situação que ela enfrenta com altivez e dignidade até os dias de hoje. Ela, com mais ou menos seis meses de idade, teria sido deixada na instituição Lar de Maria, em Belém (no Pará) por um delegado de polícia, acompanhado de um soldado, que afirmava que o bebê teria sido sequestrado. Quando ela tinha mais ou menos três anos de idade, uma mulher, Eumélia Martins, resolveu ficar com ela. Somente por volta dos nove anos de idade, ela começou a conhecer sua própria história. Mas ela conheceu melhor quando saiu uma matéria no jornal "O Estado de São Paulo", em junho de 2009 , que tratava sobre crianças sequestradas na guerrilha do Araguaia. Ela enviou um e-mail para o jornal, que a colocou de imediato em contato com uma irmã do guerrilheiro desaparecido, Antonio Teodoro Castro. Fizeram o DNA e o resultado foi positivo. Assim, ela começou a descobrir uma parte de sua história. Da mãe, ela não tem nenhuma informação.

\section{Mulheres que atuaram na repressão}

Há ainda muito a se investigar....

Um aspecto desconhecido por esses longos anos e só agora vem à tona com bastante discrição é a participação

${ }^{50}$ Marcelo GODOY, 2014, p. 146 e seguintes.

${ }^{51}$ GODOY,2014, p. 146 e seguintes.

${ }^{52}$ GODOY,2014, p. 149 de mulheres no DOI-Codi. ${ }^{50}$ Pelo menos no DOI de São Paulo, havia mulheres integradas ao corpo repressivo. Uma delas era a Tenente Neuza, nascida em 1939 na região de Bauru (SP). Entrou para a Polícia Feminina em meados de 1950 e se tornou uma das 80 mulheres policiais do país. Quando passou a Tenente no final dos anos de 1960, foi chamada para trabaIhar no DOI-Codi de São Paulo. Segundo ela: "Aí eu fui pro meu 'açougue' (DOI) e aí passaram a acreditar que a mulher também tinha capacidade". ${ }^{51}$

A tenente Neuza teria participado de ações da repressão que levaram à morte pelo menos dez pessoas e ao desaparecimento outras três: Hiram de Lima Pereira (1913-1975), José Montenegro de Lima (1943-1975) e Paulo Stuart Wright (1933-1973). ${ }^{52}$ Ela integrou a ação que culminou com o

1018 Estudos Feministas, Florianópolis, 23(3): 1001-1022, setembro-dezembro/2015 
${ }^{53}$ Depoimento dado em 10/5/2013

${ }^{54}$ GODOY,2014, p. 152.

55 GODOY, 2014, p. 153-154. sequestro dos meus filhos: Janaína Teles e Edson Teles, além da minha irmã, Crimeia de Almeida, grávida de 8 meses, no dia 29 de dezembro de 1972, e os levou, juntamente com outros policiais, sob o comando do então Major Ustra, para o DOI-Codi/SP, onde eu já me encontrava sequestrada e torturada. Só quando vi o livro A Casa da Vovó com as fotos da tenente Neuza da época é que pude confirmar que era ela mesma.

No livro citado, Neuza conta que havia mais mulheres policiais no DOI-Codi/SP. Polícia feminina só havia em São Paulo, e ela teve que preparar cinco policiais femininas para trabalhar no DOI-Codi/RJ. Parece que no DOI seu codinome era tenente Bia e era admirada por ser exímia atiradora, segundo as informações do ex-sargento do Exército, que trabalhou no DOI-Codi/SP, Marival Chaves, em seu depoimento na Comissão Nacional e Estadual da Verdade. ${ }^{53}$ Segundo ele, havia uma policial que tinha o nome de Fátima e mais de uma policial chamada de tenente Bia.

Outra policial que trabalhou no DOI, em São Paulo, foi a sargento Wilma, ${ }^{54}$ uma das participantes das operações repressivas que dizimaram o comitê central do Partido Comunista Brasileiro (PCB) e destruíram a imprensa do partido. $O$ saldo foi uma dúzia de dirigentes mortos e desaparecidos. Isso foi nos anos de 1974 e 1975. Em 1976, Wilma participou da ação juntamente com o agente infiltrado, Jover Telles, que culminou com a "chacina da Lapa", na qual foram assassinados Pedro Pomar e Ângelo Arroyo, ambos dirigentes do Partido Comunista do Brasil (PCdoB). No DOI-Codi, foi assassinado João Batista Drummond, também dirigente do PCdoB. Sargento Wilma participou também da Operação Lótus que prendeu vários militantes da Convergência Socialista em 1977.

Outra policial que também atuou no DOI-Codi/SP foi a Tenente Dyarsi. Ela trabalhou com o capitão do Exército Ênio Pimentel, cujo codinome era Dr. Ney, chefe da investigação do DOI-Codi/SP, e nos anos de 1980 foi promovida a coronel. ${ }^{55}$

\section{Conclusões}

Não há como falar da repressão, da tortura, da ditadura, sem tratar da questão das mulheres. Isso porque as muIheres tiveram uma participação intensa e generalizada em todas as organizações políticas que se encontravam na mais ferrenha clandestinidade. Do total de mortos e desaparecidos que têm seus nomes registrados, cerca de $11 \%$ são mulheres. Proporção nada desprezível se comparada com os dias de hoje, cujo resultado das últimas eleições para a Câmara de Deputados informa que 51 mulheres foram eleitas, o que significa $9,9 \%$ do total de 513 deputados eleitos. 
A ignomínia de crianças nascidas de estupros praticados por agentes de Estado existiu apesar de ser um assunto interdito ainda nos dias de hoje. O silêncio permanente que paira sobre o assunto tem muitas razões. A profunda humilhação de ser uma mulher estuprada por militares/policiais e ainda ser mãe de uma criança filha de estupro. Se ainda nos dias de hoje a palavra da mulher não tem credibilidade, imagina, então, naqueles tempos em que mulher era assunto censurado e subversivo. Não existem ainda ações políticas no sentido de oferecer condições e oportunidades para uma narrativa pública sobre o estupro e demais violências cometidas em dependências militares e policiais.

Constatamos que, na atividade clandestina, houve também avanços nas relações de gênero. Existiram ocasiões de ruptura da lógica patriarcal, até então aceita como natural de que aos homens cabe o espaço público e às mulheres, o espaço privado. Muitas vezes os homens eram obrigados a ficar em casa (ou em aparelhos), escondidos, devido à clandestinidade e às intensas perseguições, enquanto as muIheres, por passarem mais facilmente invisíveis, foram às ruas no preparo e no desencadeamento de ações políticas e militares.

É preciso criar um marco jurídico-legal que reconheça o estupro e outras violências sexuais como crime independente dos demais crimes cometidos, ainda que todos tenham sido praticados por agentes públicos e, portanto, considerados crimes de lesa-humanidade, o que os torna imprescritíveis. Os crimes sexuais praticados durante a ditadura são tão graves como outras formas de tortura utilizadas, como submeter a vítima ao pau-de-arara ou a choques elétricos, fazer "afogamentos", espancar, jogar ácido no corpo da vítima, entre outras.

Torna-se urgente reconhecer que os danos e violações de direitos humanos cometidos contra as mulheres pela ditadura militar devem ser dimensionados sob a ótica de gênero, para que se alcance com profundidade a verdade dos fatos, registrando-se que as militantes políticas, ou mesmo as que não eram, se recusaram a reproduzir o papel social de submissão e de dependência dos homens, contribuindo de maneira fundamental para a construção de uma democracia de fato, e isso num período histórico em que tudo que faltava era a democracia. A democracia atual, para ser consolidada, precisa fazer justiça às mulheres de ontem e de hoje.

A Comissão Nacional da Verdade mobilizou a opinião pública para as graves violações de direitos humanos ocorridas na ditadura militar. A entrega do Relatório Nacional não deve significar um ponto final nas investigações, pelo contrário, deve-se aprofundar as investigações e apurar as responsabilidades dos agentes públicos inclusive nos crimes 
sexuais. As consequências das práticas de torturas institucionalizadas se estendem até os dias de hoje, com ocorrência de assassinatos, estupros e ocultamento de cadáveres.

É urgente considerar as recomendações apresentadas no relatório nacional, manter a mobilização da opinião pública e implementar cada uma dessas recomendações, em especial, aquelas que exigem a apuração dos estupros e demais crimes de gênero, responsabilizando, inclusive criminalmente, os agentes públicos envolvidos.

\section{Referências}

ACTIS, Munú et al. Eseinfierno. Buenos Aires: Editora Altamira, 2006. (Coleção Memórias).

ANDÚJAR, Andreaet al. De minifaldas, militâncias y revoluciones. Exploraciones sobre los 70 enla Argentina. Buenos Aires: Luxemburg, 2009.

ARNS, Paulo Evaristo; SOBEL, Henry; WRIGHT, Jaime. Brasil: Nunca Mais. 5. ed. Petrópolis: Editora Vozes, 1985.

BRASIL. Comissão Nacional da Verdade. "Tortura". In: Relatório da Comissão Nacional da Verdade. Brasília: CNV, 2014a. v. 1, cap. 9. p. 327-380.

"Execuções e Mortes decorrentes da Tortura". In:

Relatório da Comissão Nacional da Verdade. Brasília: CNV, 2014b. v. 1, cap. 11, p. 437-487.

CODATO, Adriano Nuevo; OLIVEIRA, Marcus Roberto de. "A marcha, o terço e o livro: catolicismo conservador e ação política na conjuntura do golpe de 1964". Revista Brasileira de História, São Paulo, v. 24, n. 47, p. 271-302, 2004. Disponível em: <http://www.scielo.br/scielo.php?script=s ci_arttext\&pid $=$ S0102-0188200400010001 1 > . Acesso em: 22 dez. 2014.

COMISSÃO DE FAMILIARES DE MORTOS E DESAPARECIDOS POLÍTICOS. Dossiê Ditadura: Mortos e Desaparecidos Políticos no Brasil: 1964-1985. São Paulo: Imprensa Oficial, 2009.

CUNHA, Luiz Cláudio. "Dilema urgente da presidente Dilma: demite general ou extingue a comissão da verdade". Diário do Poder, Brasília, 22 ago. 2014. Disponível em: <http:// www.diariodopoder.com.br/noticia.php? $\mathrm{i}=18007438720>$. Acesso em: 30 maio 2015.

GODOY, Marcelo. A Casa da Vovó. Uma biografia do DOICodi (1969-1991), o centro de sequestro, tortura e morte da ditadura militar. São Paulo: Editora Alameda, 2014.

LEWIN, Miriam; WORNAT, Olga. Putas y guerrilleras. Buenos Aires: Grupo Editorial Planeta, 2014.

MARCHA da família com Deus pela liberdade. Wikipédia, 2014. Disponível em: < wikipedia.org/wiki/Marcha_da_Familia_ com_Deus_pela_Liberdade>. Acesso em: 24 dez. 2014. 
NOSSA, Leonencio. Mata! O major Curió e as guerrilhas do Araguaia. São Paulo: Companhia das Letras, 2012.

KUCINSKI, Bernardo; TRONCA, Ítalo. Pau de Arara: a violência militar no Brasil. São Paulo: Fundação Perseu Abramo, 2013.

ROSA, Susel Oliveira da. Mulheres, ditaduras e memórias. São Paulo: Editora Intermeios, 2013. (Coleção Entre gêneros).

SAFIOTTI, Heleieth. A mulher na sociedade de classes. São Paulo: Expressão Popular, 2013.

SÃO PAULO. Assembleia Legislativa. Comissão da Verdade do Estado de São Paulo "Rubens Paiva". Infância Roubada, Crianças Atingidas pela Ditadura Militar no Brasil. São Paulo: ALESP, 2014.

SERRUYA, Suzanne. Ligação de trompas: opressão e esperança. [1987?]. Texto mimeografado.

TELES, Maria Amélia de Almeida. Breve História do Feminismo no Brasil. São Paulo: Editora Brasiliense, 1993.

TELES, Amelinha; LEITE, Rosalina Santa Cruz. Da Guerrilha à Imprensa Feminista: a construção do feminismo pós luta armada (1978- 1980). São Paulo: Editora Intermeios, 2013.

[Recebido em 4 de janeiro de 2015 e aceito para publicação em 15 de março de 2015]

\section{Human Rights Violations of Women in Dictatorship}

Abstract: The article comments on the general situation of Brazilian women in the years of 1960 and 1970 emphasizing the women participation in the fight against the dictatorship and the modus operandi of the misogynist oppressive system that used the body, the sexuality and the maternity to intensify the torture or cruelly exterminate some militants women. It highlights the political role of the Truth Commission for giving voice to the victims: women that could only speak in public for the first time after over four decades of the occurred facts. The text also proposes that sex crimes and gender crimes come to be properly investigatedand the responsibilities determined even after 40 years for being those crimes against humanity.

Key Words: Dictatorship; Gender Crimes; Torture; Women; Rape. 